\title{
Inhibitory Effects of Selected Antiviral Compounds on Newly Isolated Clinical Varicella-Zoster Virus Strains
}

\author{
Masanori Baba, Kenji Konno, Shiro Shigeta and Erik \\ De ClercQ* \\ Department of Bacteriology, Fukushima Medical College, \\ Fukushima 960, and *Rega Institute for Medical Research, \\ Katholieke Universiteit Leuven, Leuven, Belgium
}

\begin{abstract}
Baba, M., Konno, K., Shigeta, S. and De Clercq E. Inhibitory Effects of Selected Antiviral Compounds on Newly Isolated Clinical Varicella-Zoster Virus Strains. Tohoku J. exp. Med., 1986, 148 (3), 275-283 — Nine anti-herpes compounds, idoxuridine (IDU), bromovinyldeoxyuridine (BVDU), bromovinylarabinofuranosylurasil (BVaraU), carbocyclic bromovinyldeoxyuridine (C-BVDU), chloroethyldeoxyuridine (CEDU), acyclovir (ACV), dihydroxypropoxymethylguanine (DHPG), adenine arabinoside (Ara-A), and phosphonoformate (PFA) were examined for their inhibitory activities against the replication of twenty-six newly isolated clinical strains of varicella-zoster virus (VZV) in human embryonic fibroblast cell cultures. The order of (decreasing) efficacy was : BVaraU $>$ BVDU $\geq \mathrm{C}-\mathrm{BVDU}>\mathrm{CEDU} \geq \mathrm{IDU}>\mathrm{ACV}>\mathrm{Ara}-\mathrm{A}>\mathrm{DHPG}>\mathrm{PFA}$. There was little variation in the susceptibility of the $26 \mathrm{VZV}$ strains to each particular compound, except for one strain which was resistant to IDU._—_ varicella-zoster virus ; anti-herpes drugs; antiviral activity; clinical isolates
\end{abstract}

The severe and occasionally fatal varicella-zoster virus (VZV) infections that may occur in immunosuppressed patients remain a major challenge for antiviral chemotherapy (Balfour et al. 1983). Acyclovir [9-(2-hydroxyethoxymethyl) guanine, $\mathrm{ACV}]$ and vidarabine $[9-\beta$-D-arabinofuranosyladenine (ara-A)] have both been licenced for the systemic, i.e., intravenous, treatment of these infections (De Clercq 1984). A promising candidate drug for the treatment of VZV infections in immunosuppressed patients is $(E)-5$-(2-bromovinyl)-2'-deoxyuridine (BVDU). The compound can be administered perorally, and has already been the subject of initial clinical trials (Benoit et al. 1985; Wildiers and De Clercq 1984).

Among the problems linked to the current generation of anti-herpes compounds (De Clercq 1984) is their narrow activity spectrum. ACV is highly active against herpes simplex virus (HSV) type 1 and 2, but less active to VZV, cytomegalovirus (CMV), and Epstein-Barr virus (EBV) (Elion et al. 1977 ;

Received December 23, 1985 ; accepted for publication February 4, 1986. 
Schaeffer et al. 1978; Biron and Elion 1980; Colby et al. 1980 ; Balfour et al. 1982). BVDU is higly inhibitory to HSV-1 and VZV, but less so to HSV-2, CMV, and EBV (De Clercq et al. 1979, 1980 ; Shigeta et al. 1983; De Clercq 1984). Another problem associated with the use of anti-herpes compound is the emergence of drug resistant mutant strains. Such drug-resistant HSV strains have been reported for ACV (Burns et al. 1982; Crumpacker et al. 1982), and an experimental VZV strain, designated Kanno-Kohmura, was found resistant to both ACV and BVDU (Shigeta et al. 1983).

$\mathrm{ACV}, \mathrm{BVDU}$ and various other anti-herpes compounds were previously evaluated for their inhibitory effects on different VZV strains in vitro (Shigeta et al. 1983 ; Muto et al. 1984). As in the mean time several new compounds have been developed, we intended to compare their in vitro activity against VZV with the anti-VZV activity of a number of antiherpetic drugs which are now in clinical use. Furthermore, to enable a more accurate prediction of their antiviral efficacy in patients, all compounds were evaluated against a broad range (26 new clinical isolates) of VZV strains.

\section{Materials and Methods}

Viruses

The twenty-six strains of VZV were all freshly isolated clinical samples, of which 13 strains were isolated from patients with varicella and the other 13 strains from patients with herpes zoster. Fifteen of the 26 patients had an underlying malignant disorder. Eight patients had acute lymphocytic leukemia (ALL), two had acute myelocytic leukemia (AML), two had hepatoblastoma, one had chronic lymphocytic leukemia (CLL), one had malignant lymphoma, and one had rhabdomyosarcoma. The laboratory strain CaQu was provided by N.J. Schmidt (Viral and Rickettsial Disease Laboratory, Department of Health, Barkeley, California, USA). The Kanno-Kohmura strain is a deoxythymidine (dThd) kinase-deficient $\left(\mathrm{TK}^{-}\right)$VZV mutant described previously (Shigeta et al. 1983). Cell-free virus was obtained by sonic treatment of infected cells, as described by Schmidt and Lennette (1976), and stored at $-80^{\circ} \mathrm{C}$ until used.

Cells

Human embryonic fibroblast (HEF) cells were grown in Eagle's minimum essential medium (MEM) supplemented with 10\% heat inactivated newborn calf serum (NCS), 100 units $/ \mathrm{ml}$ penicillin $\mathrm{G}$ and $50 \mu \mathrm{g} / \mathrm{ml}$ streptomycin (growth medium).

Compounds

The sources, references and abbreviations of the test compounds are listed in Table 1.

Antiviral activity assay

All assays were carried out in confluent HEF monolayers in Falcon multiwell plates with 24 flat bottom wells of $16 \mathrm{~mm}$ diameter (Becton Dickinson Labware, California, USA). The HEF monolayers were infected with approximately 50 plaque forming units (PFU) of virus per well, and immediately thereafter exposed to varying concentrations of the compounds $(125,25,5,1,0.2,0.04,0.008,0.0016$ and $0.00032 \mu \mathrm{g} / \mathrm{ml})$ in maintenance medium (MEM, 2\% NCS and antibiotics at the concentrations mentioned above). All tests were run in duplicate. The monolayers were incubated at $37^{\circ} \mathrm{C}$ for $72 \mathrm{hr}$, and the $\mathrm{VZV}$ foci were 
TABLE 1. Anti-herpes compounds used in the present study

\begin{tabular}{|c|c|c|}
\hline Compound & Abbreviation & Source reference \\
\hline 5-Iodo-2'-deoxyuridine & IDU & Sigma Chemical Co., St. Louis, MO \\
\hline $\begin{array}{l}(E)-5 \text {-(2-bromovinyl)-2' } \\
\text { deoxyuridine }\end{array}$ & BVDU & De Clercq et al. (1979) \\
\hline $\begin{array}{l}1-\beta \text {-D-Arabinofuranosyl- }(E)-5-(2- \\
\text { bromovinyl) uracil }\end{array}$ & BVaraU & Yamasa Shoyu Co., Choshi, Japan \\
\hline $\begin{array}{l}\text { Carbocyclic }(E)-5 \text {-(2-bromovinyl)- } \\
2^{\prime} \text {-deoxyuridine }\end{array}$ & C-BVDU & Herdewijn et al. (1985) \\
\hline 5-(2-Chloroethyl)-2'-deoxyuridine & CEDU & Rosenwirth et al. (1985) \\
\hline $\begin{array}{l}\text { 9-(2-Hydroxyethoxymethyl) } \\
\text { guanine }\end{array}$ & $\mathrm{ACV}$ & $\begin{array}{l}\text { Burroughs Wellcome, Research Tri- } \\
\text { angle Park, NC }\end{array}$ \\
\hline $\begin{array}{l}\text { 9-(1,3-Dihydroxy-2-propoxymethyl) } \\
\text { guanine }\end{array}$ & DHPG & Field et al. (1983) \\
\hline $9-\beta$-D-Arabinofuranosyladenine & Ara-A & Parke Davis Co., Ann Arbor, MI \\
\hline Phosphonoformic acid & PFA & $\begin{array}{l}\text { Astra Läkemedel AB, Södertälje, } \\
\text { Sweden }\end{array}$ \\
\hline
\end{tabular}

scored by immuno-peroxidase method. Briefly, after removal of the maintenance medium, the monolayers were washed twice phosphate-buffered saline (PBS), pH 7.2, and fixed with $100 \%$ methanol at $4^{\circ} \mathrm{C}$ for $10 \mathrm{~min}$. Then they were treated with a proper dilution of anti-VZV human convalescent serum for $30 \mathrm{~min}$ at $37^{\circ} \mathrm{C}$. After being washed twice with PBS, they were treated with peroxidase-conjugated rabbit antibody to human IgG (Dakopatts a/s, Denmark) for $30 \mathrm{~min}$ at $37^{\circ} \mathrm{C}$, and again washed twice with PBS. To each well was then added $0.5 \mathrm{ml}$ of substrate solution containig $0.5 \mathrm{mg} / \mathrm{ml} 3,3^{\prime}$-diaminobenzidinetetrahydrochloride, 0.05 M Tris (hydroxymethyl) aminomethane, $0.2 \mathrm{M} \mathrm{NaCl}$, and $0.01 \% \mathrm{H}_{2} \mathrm{O}_{2}$. The plates were left for $15 \mathrm{~min}$ in a dark room. The VZV foci appeared as light brown ; they were enumerated under a magnifying glass.

The antiviral potency is expressed as $\mathrm{ID}_{50}$, that is the concentration of compound required to reduce the number of foci to $50 \%$ of that in the control cell cultures (infected with virus but not exposed to antiviral compounds).

\section{Cytotoxicity assay}

Cytotoxicity of the compounds against HEF was examined by the trypan blueexclusion test as previously described (Shigeta et al. 1983).

\section{RESUlts}

\section{Susceptibility of the clinical VZV isolates of the antiviral compounds}

The $\mathrm{ID}_{50}$ values of the 9 test compounds for the 26 clinical VZV isolates are depicted in Fig. 1A and 1B. With an average $\mathrm{ID}_{50}$ of $0.0011,0.011$ and $0.014 \mu \mathrm{g} /$ $\mathrm{ml}$ respectively, $\mathrm{BV}$ araU, $\mathrm{BVDU}$ and $\mathrm{C}-\mathrm{BVDU}$ emerged as the most potent inhibitors of VZV replication. Then followed CEDU which was slightly more potent than IDU. DHPG was less potent than ACV and Ara-A, and PFA was the least potent of the 9 compounds tested (Fig. $1 \mathrm{~A}$ and B).

There was little variation in the susceptibility of the $26 \mathrm{VZV}$ stratins to each particular compound, except for the Ito strain. The $\mathrm{ID}_{50}$ value of IDU for the Ito 

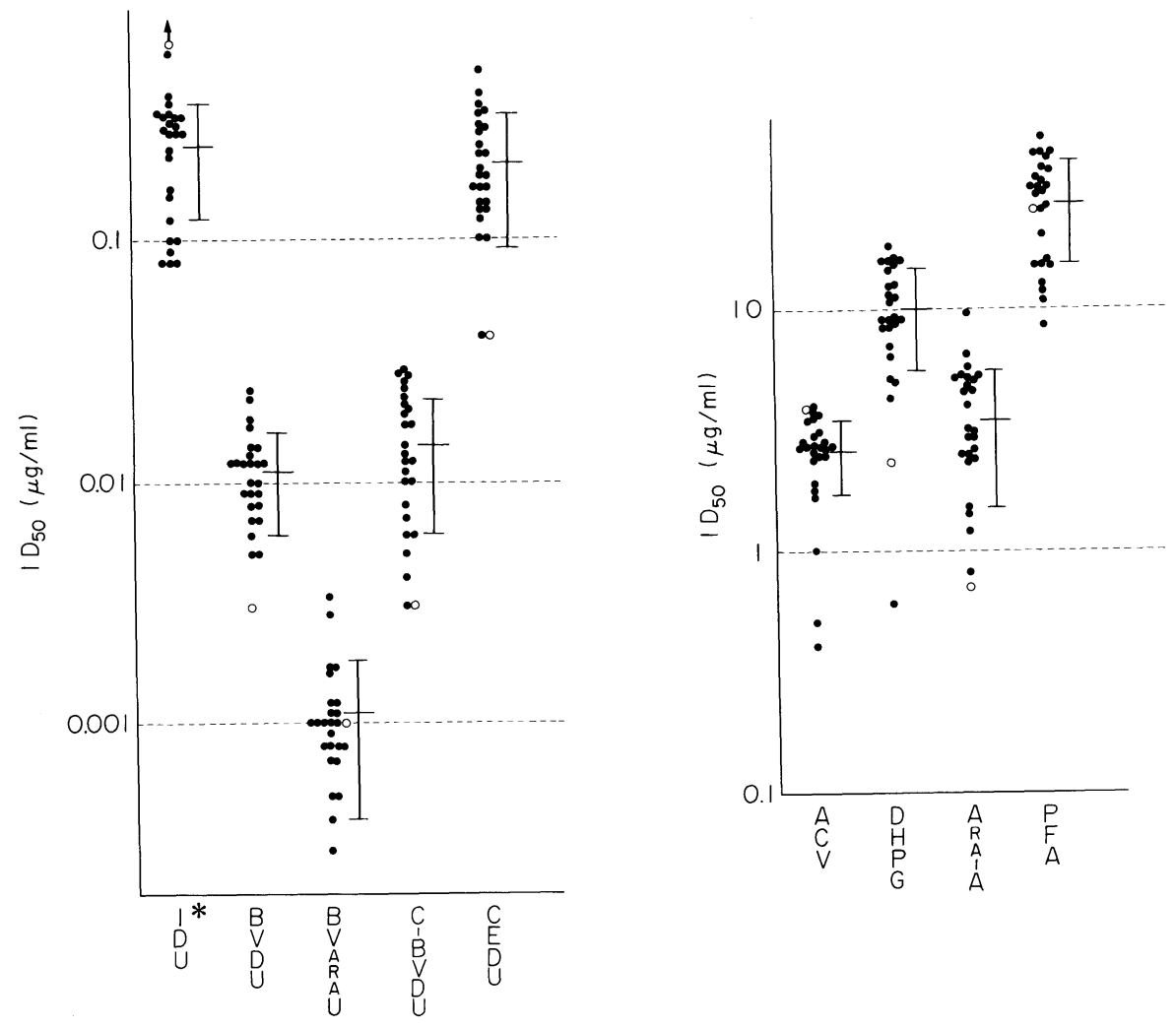

Fig. 1A, 1B Susceptibility of twenty-six newly isolated clinical VZV strains to nine anti-herpes compounds in HEF cell cultures. For each compound the individual $\mathrm{ID}_{50}$ values $(\bullet)$, as well as the average $\mathrm{ID}_{50}$ values and standard deviations (-), are indicated. The Ito strain, which is resistant to IDU, is indicated by $(O)$. When calculating the average $\mathrm{ID}_{50}$ value for IDU, the Ito strain was excluded $(*)$.

strain was $4.22 \mu \mathrm{g} / \mathrm{ml}$, that is more than 10 -fold higher than the average $\mathrm{ID}_{50}$ value for the 25 other VZV strains $(0.24 \mu \mathrm{g} / \mathrm{ml})$. In its sensitivity to C-BVDU, CEDU, DHPG, the Ito strain did not markedly differ from the other VZV strains (Fig. 1A, 1B). There was no difference between the susceptibility pattern of VZV strains isolated from varicella patients and that of VZV strains isolated from zoster patients (data not shown).

\section{Susceptibility of the laboratory VZV strain and $T K^{-} V Z V$ strain}

In addition to the 26 clinical VZV isolates, a laboratory VZV strain (CaQu) and a TK- VZV mutant strain (Kanno-Kohmura) were examined for their susceptibility to the inhibitory effects of the 9 test compounds. Table 2 shows the $\mathrm{ID}_{50}$ of the compounds for these two strains and the average $\mathrm{ID}_{50}$ of the compounds for the 26 clinical strains. The CaQu strain was as susceptible at the clinical strains. 
TABLE 2. Susceptibility of 26 new clinical VZV isolates, a laboratory VZV strain ( $\mathrm{CaQu}$ ) and a deoxymidine kinase-deficient (TK ${ }^{-}$) VZV strain (Kanno-Kohmura) to the inhibitory effects of nine selected antiviral compounds in HEF cell cultures

\begin{tabular}{lccc}
\hline & \multicolumn{3}{c}{$\mathrm{ID}_{50} \dagger(\mu \mathrm{g} / \mathrm{ml})$} \\
\cline { 2 - 4 } Compound & $\begin{array}{c}\text { Average }( \pm \text { s.D. }) \text { for } \\
26 \text { new clinical isolates }\end{array}$ & CaQu strain & $\begin{array}{c}\text { Kanno-Kohmura } \\
\text { strain }\end{array}$ \\
\hline IDU & $0.24 \pm \pm 0.12$ & 0.30 & 6.21 \\
BVDU & $0.011 \pm 0.005$ & 0.011 & $>1.0$ \\
BVaraU & $0.0011 \pm 0.0007$ & 0.0004 & $>1.0$ \\
C-BVDU & $0.014 \pm 0.008$ & 0.020 & $>1.0$ \\
CEDU & $0.20 \pm 0.11$ & 0.18 & $>10.0$ \\
ACV & $2.6 \pm 0.9$ & 1.8 & 21.4 \\
DHPG & $10.1 \pm 4.6$ & 10.3 & 76.2 \\
Ara-A & $3.5 \pm 2.0$ & 1.9 & 0.6 \\
PFA & $27.2 \pm 12.2$ & 30.0 & 20.0 \\
\hline
\end{tabular}

*See Table 1 for abbreviations. $\lceil 50 \%$ inhibitory dose. $\ddagger$ Ito strain excluded.

The $\mathrm{TK}^{-}$mutant strain was resistant to IDU, BVDU, BVaraU and ACV (Shigeta et al. 1983), and also resistant to C-BVDU, CEDU and DHPG (Table 2). However, it was equally sensitive to Ara-A and PFA as the clinical VZV isolates and the CaQu strain.

\section{Cytotoxicity}

By the trypan blue-exclusion test no reduction in cell viability was observed with any of the compounds, even when assayed at $125 \mu \mathrm{g} / \mathrm{ml}$ (the highest concentration tested). When the $\mathrm{C}-\mathrm{BVDU}, \mathrm{CEDU}$, and $\mathrm{DHPG}$ (the most recently developed anti-herpes compounds) were examined for their inhibitory effects on the growth of uninfected HEF cells, again on toxicity for the host cells was noted at a concentration of $125 \mu \mathrm{g} / \mathrm{ml}$. For C-BVDU, CEDU and DHPG the lack of host cell toxicity is in line of what has been reported by other investigators (Tocci et al. 1984 ; Herdewijn et al. 1985 ; Rosenwirth et al. 1985).

\section{Discussion}

Since our previous evaluation of the inhibitory effects of various antiviral compounds on VZV replication in vitro (Shigeta et al. 1983), several new compounds, i.e., DHPG, C-BVDU and CEDU, have been developed as candidate anti-herpes drugs.

DHPG is an acyclic nucleoside analog related to ACV. It has proven active against HSV-1, HSV-2, VZV, CMV and EBV (Smith et al. 1982; Field et al. 
1983 ; Mar et al. 1983). Previous studies have demonstrated that DHPG is as effective as ACV in the inhibition of VZV (Field et al. 1983; Collins and Oliver 1985). In the present study the average $\mathrm{ID}_{50}$ value of $\mathrm{DHPG}$ for 26 clinical VZV strains was 4-fold higher than that of ACV (Fig. 1B). However, this result does not per se discredit the therapeutic potential of DHPG against VZV infections, for in animal model HSV infections DHPG is more efficacious than than ACV (Field et al. 1983, 1984; Collins and Oliver 1985) probably because of a better bioavailability of the active metabolite (DHPG triphosphate). Furthermore, it has been demonstrated that the combinations of interferon and DHPG have synergistic antiviral effects on HSV replication in vitro and in vivo (Eppstein and Marsh 1984 ; Fraser-Smith et al. 1984). Our preliminary investigations (data not shown) indicate that DHPG and interferon may also have synergistic inhibitory effect on VZV replication in vitro.

C-BVDU, a carbocyclic analog of BVDU, is resistant to degradation by pyrimidine nucleoside phosphorylases, i.e., 2 '-deoxythymidine phosphorylase (Herdewijn et al. 1985). BVDU is readily degraded by this enzyme to its free base (E)-5-(2-bromovinyl) uracil (BVU), which is as such inactive as an antiviral agent, and this degradation accounts for the rapid clearance of BVDU from the bloodstream upon systemic administration Desgranges et al. 1983. Because of its protection against premature degradation by nucleoside phosphorylases, C-BVDU might be expected to be more effective than BVDU in vivo. It is, therefore, noteworthy that in vitro C-BVDU was equally potent as BVDU in inhibiting VZV replication (Fig. 1A).

CEDU can be considered as a BVDU derivative in which the halovinyl side chain has been saturated to an haloethyl. It has recently been evaluated for its inhibitory activities against HSV infections in vitro and in vivo (Rosenwirth et al. 1985). CEDU has proven highly efficacious in several experimental HSV-1 model infections in mice; i.e., against systemic HSV-1 infections and HSV-1 encephalitis, it was effective at a 5- to 15-fold lower dose than ACV and BVDU. From our present results CEDU appeared to be 20 -fold less potent than BVDU but 10 -fold more potent than ACV in inhibiting VZV replication in vitro (Fig. 1A, 1B).

IDU, BVDU, BVaraU, ACV, Ara-A and PFA, which were subject of a previous study on their inhibitory effects against laboratory VZV strains in vitro (Shigeta et al. 1983), were re-evaluated for their inhibitory activities against clinical VZV strains. In general, the $\mathrm{ID}_{50}$ values recorded for these compounds (Fig. 1A, 1B) were similar to those reported previously (Shigeta et al. 1983). However, the $\mathrm{ID}_{50}$ value of BVDU for the clinical isolates $(0.011 \mu \mathrm{g} / \mathrm{ml})$ was higher than that reported for the laboratory strains $(0.0024 \mu \mathrm{g} / \mathrm{ml})$. This may be due to differences in the virus strains, host cells, or method of VZV focus detection. Thus, BVaraU was, at an average, 10 times more potent against VZV than BVDU, which is in agreement with the data of Machida et al. (1982). Yet, the $\operatorname{ID}_{50}(0.011$ 
$\mu \mathrm{g} / \mathrm{ml}$ ) of BVDU for VZV is far below the plasma drug levels $[0.5-1 \mu \mathrm{g} / \mathrm{ml}$ (data not shown)] achieved upon oral administration of BVDU at therapeutically effective doses (Wildiers and De Clercq 1984; Benoit et al. 1985).

The anti-VZV activity of IDU, BVDU, BVaraU, C-BVDU, CEDU, ACV and DHPG depends on a specific phosphorylation by the virus-induced dThd kinase, since these compounds are much less inhibitory to the $\mathrm{TK}^{-}$mutant KannoKohmura strain than the wild-type VZV strains (Table 2). The residual activity shown by IDU against the Kanno-Kohmura strain may be due to an inhibitory effect of IDU on host cell DNA synthesis (Shigeta et al. 1983).

With the exception of the Ito strain which was resistant to IDU, none of the 26 clinically isolated VZV strains proved to be resistant to any of the test compounds. It is possible, however, that as the clinical use of anti-herpes drugs increases, drug-resistant mutant strains may arise with increased frequency. To have the appropriate antiviral drug at hand when necessary, clinical VZV isolates from the population at large should be regularly examined for their susceptiblity to the available anti-VZV agents.

\section{References}

1) Balfour, H.H., Bean, B., Mitchell, C.D., Sachs, G.W., Bone, J.R. \& Edelman, C.K. (1982) Acyclovir in immunocompromised patients with cytomegalovirus disease. Amer. J. Med., 73, 241-248.

2) Balfour, H.H., Bean, B., Laskin, O.L., Ambinder, R.F., Meyers, J.D., Wade, J.C., Zaia, J.A., Aeppli, D., Krik, L.E., Segreti, A.C., Keeney, R.E. \& the Burroughs Wellcome Collaborative Acyclovir Study Group. (1983) Acyclovir halts progression of herpes zoster in immunocompromised patients. New Engl. J. Med., 308, 1448-1453.

3) Benoit, Y., Laureys, G., Delbeke, M.J. \& De Clercq, E. (1985) Oral BVDU treatment of varicella and zoster in children with cancer. Europ. J. Pediat., 143, 198-202.

4) Biron, K.K. \& Elion, G.B. (1980) In vitro susceptibility of varicella-zoster virus to acyclovir. Antimicrob. Agents Chemother., 18, 443-447.

5) Burns, W.H., Saral, R., Santos, G.W., Laskin, O.L., Lietman, P.S., McLaren, C. \& Barry, D.W. (1982) Isolation and characterization of resistant herpes simplex virus after acyclovir therapy. Lancet, 1, 421-423.

6) Colby, B.M., Shaw, J.E., Elion, G.B. \& Pagano, J.S. (1980) Effect of acyclovir [9-(2-hydroxyethoxymethyl) guanine] on Epstein-Barr virus DNA replication. $J$. Virol., 34, 560-568.

7) Collins, P. \& Oliver, N.M. (1985) Comparison of the in vitro and in vivo antiherpes virus activities of acyclic nucleosides, acyclovir (Zovirax) and 9-[(2-hydroxy-1hydroxymethylethoxy) methyl] guanine (BWB759U). Antiviral Res., 5, 145-156.

8) Crumpacker, C.S., Schnipper, L.E., Marlowe, S.I., Kowalsky, P.N., Hershey, B.J. \& Levin, M.J. (1982) Resistance to antiviral druges of herpes simplex virus isolated from a patient treated with acyclovir. New Engl. J. Med., 306, 343-346.

9) De Clercq, E. (1984) Antiherpes drugs: promises and pitfalls. Europ. J. clin. Microbiol., 3, 96-107.

10) De Clercq, E., Descamps, J., De Somer, P., Barr, P.J., Jones, A.S. \& Walker, R.T. (1979) (E)-5-(2-bromovinyl)-2'-deoxyuridine: a potent and selective anti-herpes agent. Proc. nat. Acad. Sci. USA, 76, 2947-2951.

11) De Clercq, E., Descamps, J., Verhelst, G., Walker, R.T., Jones, A.S., Torrence, P.F. \& Shugar, D. (1980) Comparative efficacy of antiherpes drugs against different strains 
of herpes simplex virus. $J$. Infect. Dis., 141, 563-574.

12) Desgranges, C., Razaka, G., Rabaud, M., Bricaud, H., Balzarini, J. \& De Clercq, E. (1983) Phosphorolysis of (E)-5-(2-bromovinyl)-2'-deoxyuridine (BVDU) and other 5 -substituted-2'-deoxyuridines by purified human thymidine phosphorylase and intact blood platelets. Biochem. Pharmacol., 32., 3583-3590.

13) Elion, G.B., Furman, P.A., Fyfe, J.A., de Miranda, P., Beauchamp, L. \& Schaeffer, H. J. (1977) Selectivity of action of antiherpetic agent, 9-(2-hydroxyethoxymethyl) guanine. Proc. nat. Acad Sci. USA. 74, 5716-5720.

14) Eppstein, D.A. \& Marsh, Y.V. (1984) Potent synergistic inhibition of herpes simplex virus-2 by 9 -[(1, 3-dihydroxy-2-propoxy) methyl] guanine in combination with recombinant interferons. Biochem. biophys. Res. Commun., 120, 66-73.

15) Field, A.K., Davies, M.E., DeWitt, C., Perry, H.C., Liou, R., Germershausen, J., Karkas, J.D., Ashton, W.T., Johnston, D.B.R. \& Tolman, R.L. (1983) 9-\{[2-hydroxy1-(hydroxymethyl) ethoxy] methyl $\}$ guanine: a selective inhibitor of herpes group virus replication. Proc. nat. Acad. Sci. USA., 80, 4139-4143.

16) Field, H.J., Anderson, J.R. \& Efstathiou, S. (1984) A quantitative study of the effects of several nucleoside analogues on established herpes encephalitis in mice. $J$. gen. Virol., 65, 707-719.

17) Fraser-Smith, E.B., Eppstein, D,A., Marsh, Y.V. \& Matthews, T.R. (1984) Enhanced efficacy of the acyclic nucleoside 9-(1,3-dihydroxy-2-propoxymethyl) guanine in combination with beta-interferon against herpes simplex virus type 2 in mice. Antimicrob. Agents Chemother., 25, 563-565.

18) Herdewijn, P., De Clercq, E., Balzarini, J. \& Vanderhaeghe, H. (1985) Synthesis and antiviral activity of the carbocyclic analogues of $(E)-5$-(2-halovinyl)-2'-deoxyuridines and (E)-5-(2-halovinyl)-2'-deoxycytidines. J.med. Chem., 28, 550-555.

19) Machida, H., Kuninaka, A. \& Yoshino, H. (1982) Inhibitory effects of anti-herpesviral thymidine analogs against varicella-zoster virous. Antimicrob. Agents Chemother., 21, 358-361.

20) Mar, E.-C., Cheng, Y.C. \& Huang, E.S. (1983) Effect of 9-(1, 3-dihydroxy-2propoxymethyl) guanine on human cytomegalovirus replication in vitro. Antimicrob. Agents Chemother., 24, 518-521.

21) Muto, S., Suzuki, H., Yokota, T. \& Shigeta, S. (1984) Effects of acyclovir on herpes virus infection and susceptibility of isolated virus to acyclovir. Fukushima, J. Med. Sci., 30, 19-27.

22) Rosenwirth, B., Griengl, H., Wanek, E. \& De Clercq, E. (1985) 5-(2-Chloroethyl)-2'deoxyuridine: a potent and selective inhibitor of herpes viruses in vitro and in vivo. Antiviral Res., Suppl. 1, 21-28.

23) Schaeffer, H.J., Beauchamp, L., de Miranda, P., Elion, G.B., Bauer, D.J. \& Collins, P. (1978) 9-(2-Hydroxyethoxymethyl) guanine activity against viruses of the herpes group. Nature, 272, 583-585.

24) Schmidt, N.J. \& Lennette, E.H. (1976) Improved yield of cell-free varicella-zoster virus. Infect. Immun., 14, 709-715.

25) Shigeta, S., Yokota, T., Iwabuchi, T., Baba, M., Konno, K., Ogata, M. \& De Clercq, E. (1983) Comparative efficacy of antiherpes drugs against various strains of varicellazoster virus. J. infect. Dis., 147, 576-584.

26) Smith, K.O., Galloway, K.S., Kennell, W.L., Ogilvie, K.K. \& Radatus, B.K. (1982) A new nucleoside analogue, 9-[[2-hydroxy-1-(hydroxymethyl) ethoxy] methyl] guanine, highly active in vitro against herpes simplex type 1 and 2. Antimicrob. Agents Chemother., 22, 55-61.

27) Tocci, M.J., Livelli, T.J., Rerry, H.C., Crumpacker, C.S. \& Field, A.K. (1984) Effect of the nucleoside analog 2'-nor-2'-deoxyguanosine on human cytomegalovirus replication. Antimicrib. Agents Chemother., 25, 247-252.

28) Wildiers, J. \& De Clercq, E. (1984) Oral (E)-5-(2-bromovinyl)-2'-deoxyuridine 
treatment of severe herpes zoster in cancer patients. Europ. J. Cancer clin. Oncol., 20, 471-476. 